\title{
Farmers say Monsanto's engineered cotton drops bolls
}

As the fall harvest began, more than 40 US cotton growers in the Mississippi Delta region had filed complaints with the state agriculture commission over Monsanto's (St. Louis, MO) Roundup Ready cotton. Claiming heavy losses, the Mississippi farmers are saying that large numbers of these genetically engineered, herbicide-tolerant plants are dropping their cotton bolls before harvest or are producing deformed bolls. In response, Monsanto representatives point out that these problems are confined to a tiny portion of total US cotton acreage, that Roundup Ready cotton planted in other states and elsewhere in Mississippi is performing well, and something other than

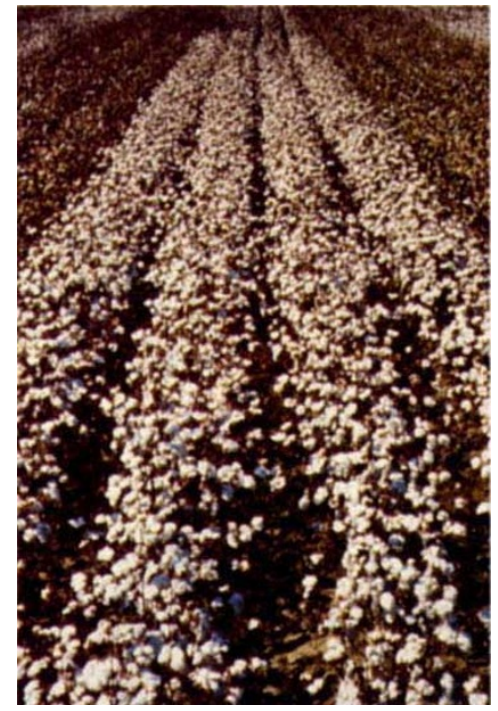

Mississippi farmers have been less than "bolled" over by Monsanto's Roundup Ready cotton.
So far, although officials from the US Department of Agriculture (USDA; Washington, DC) are not directly involved with the developing situation in Mississippi, regional officials who specialize in cotton are monitoring the developments. Under Mississippi state law, however, growers may file complaints about problem-associated seeds with the Mississippi State Department of Agriculture (Jackson, MS), whose commissioner is authorized to set up a Seed Arbitration Council.

This relatively new and untested law specifies procedures under which the council mediates disputes between growers and seed suppliers, according to Tommy McDaniel, an official transgenic changes to the cotton seed surely account for these peculiar developments.

Although Roundup Ready cotton was planted as part of field trials in earlier years, the 1997 growing season is the first time it was planted commercially, with Monsanto making transgenic seed available through Delta and Pine Land Co. (Scott, MS). Genetic changes enable the plants to withstand treatment with the broad-spectrum herbicide, glyphosate, which Monsanto markets under the tradename Roundup. Tolerance for this low-residue herbicide, which is used to control weeds and thereby boost crop yields, has also been engineered into other major field crops, such as soybeans.

Mississippi is among the top cotton producing states. The 1996 cotton crop in Mississippi generated close to 2 million bales of product from more than 1.1 million acres, with yields averaging more than 800 pounds per acre. Despite suggestions that problems may be more widespread, formal complaints about Monsanto's transgenic cotton involve plantings on a small fraction of that total acreage-about 30,000 acres in one region of the state. Within that Mississippi Delta region, some farmers claim they face staggering losses of up to $\$ 500,000$ for this year's cotton crop. with the state agriculture department. Subsequently, the council "can make recommenda-

In response to complaints filed by growers since July, the department dispatched inspectors to visit each affected field, map and inspect cotton plants, and assemble a tions, but they are not binding," he says.
At the end of September, Boston Life Sciences (Boston, MA) announced the failure of Therafectin, its synthetic monohydrate pentose drug for the treatment of arthritis. This followed the failure in August of Alpha-Beta Technologies' (Worcester, MA) antiinfective glucose polymer, Betafectin. Despite poor results, however, these two companies and others still believe that carbohydrates have significant potential both as drugs and drug targets.

The phase III trial Therafectin arthritis was ambivalent: While $40 \%$ of patients on Therafectin saw some improvement, this percentage was closely matched by the placements. Despite these results, David Hillson, bo group, in which $33 \%$ showed improve- database, McDaniel says. Those inspectors "are seeing extensive problems of aborted and deformed bolls," he says. "It's serious and very extensive for some farms in which every acre may be planted with Roundup Ready varieties. In these fields, the deformities are very common."

By early October, a few cotton growers were still filing complaints with the Seed Arbitration Council, which had not issued any recommendations. However, because the council has little authority to enforce its recommendations, the stage seems set for civil lawsuits.

Indeed, local attorneys at Merkel \& Cocke (Clarksdale, MS) appear poised for just such action. "We're now representing seven or eight local farmers," says the firm's W. Stephens Cox. "There is a multitude of problems with this Roundup Ready stuff." Thus, he attributes the boll drop-off and deformity problems of the transgenic cotton to a "gene that went crazy." And he points to "another problem," arising for farmers who grow the transgenic cotton and then treat fields with Roundup. "Glyphosate may be getting into the cotton seeds, some of which are used for oil in foods," he says.

"For some farmers, it's a nightmare and their whole crop is a loss, with poor yields and low quality cotton," says Cox. "If litigation goes forward, we could be talking millions of dollars in damages."

Jeffrey L. Fox

\section{Carbohydrates down, but not out}

CEO and president of Boston Life Sciences, has not given up on Therafectin. The drug showed efficacy for swollen joints, he says. "We will submit data [from the phase III trial] to an outside panel to find out if practicing physicians would want to have Therafectin. If the answer is yes we will put it before the FDA [US Food and Drug Administration; Rockville, MD]," he explains.

If, on the other hand, the answer from the physicians is no, Hillson says he would ask himself "what's the use of this?" and would have to drop not just Therafectin, but the whole carbohydrate program at Boston Life Sciences. Therafectin has cost $\$ 90$ million to develop, and Hillson does not believe that 